\title{
Erratum to: Quality of reporting of randomised controlled trials in chiropractic using the CONSORT checklist
}

Fay Karpouzis ${ }^{{ }^{*}}$, Rod Bonello ${ }^{2}$, Mario Pribicevic ${ }^{3}$, Allan Kalamir ${ }^{3}$ and Benjamin T. Brown ${ }^{3}$

\section{Erratum}

It has been brought to our attention that the last statement in the Results section of the Abstract of this article [1] is incorrect. This currently reads as: "Multivariate regression analysis, revealed that year of publication $\left(t_{32}=5.17, p=0.000,95 \% \mathrm{CI}: 0.76,1.76\right)$, and sample size $\left(t_{32}=3.01, p=0.005,95 \% \mathrm{CI}: 1.36,7.02\right)$, were the only two factors associated with reporting quality". The error is the test statistic for the year of publication. It should be: "Multivariate regression analysis, revealed that year of publication $\left(t_{32}=1.26, p=0.000,95 \% \mathrm{CI}: 0.76\right.$, 1.76), and sample size ( $t_{32}=3.01, p=0.005,95 \%$ CI: 1.36 , $7.02)$, were the only two factors associated with reporting quality".

\section{Author details}

'PO Box 2108, Rose Bay Nth, NSW 2030, Australia. ${ }^{2}$ School of Health Professions, Murdoch University, South St., Murdoch, WA 6150, Australia. ${ }^{3}$ Department of Chiropractic, Macquarie University, Balaclava Rd., North Ryde, NSW 2109, Australia.

Received: 15 August 2016 Accepted: 15 August 2016

Published online: 17 August 2016

\section{Reference}

1. Karpouzis F, Bonello R, Pribicevic M, Kalamir A, Brown BT. Quality of reporting of randomised controlled trials in chiropractic using the CONSORT checklist. Chiropr Man Therap. 2016;16(24).

* Correspondence: faykchiro@optusnet.com.au

${ }^{1}$ PO Box 2108, Rose Bay Nth, NSW 2030, Australia

Full list of author information is available at the end of the article

Submit your next manuscript to BioMed Central and we will help you at every step:

- We accept pre-submission inquiries

- Our selector tool helps you to find the most relevant journal

- We provide round the clock customer support

- Convenient online submission

- Thorough peer review

- Inclusion in PubMed and all major indexing services

- Maximum visibility for your research

Submit your manuscript at www.biomedcentral.com/submit 